\author{
Luiza Wieczorek \\ ORCID 0000-0002-5843-099X \\ Uniwersytet Łódzki \\ Instytut Nauk o Ziemi, Katedra Meteorologii i Klimatologii \\ wieczorek-luiza@o2.pl \\ Wiktor Piech \\ ORCID 0000-0001-5068-1631 \\ Uniwersytet Łódzki \\ Instytut Nauk o Ziemi, Katedra Geomorfologii i Paleogeografii \\ wiktor.piech@geo.uni.lodz.pl \\ Bartłomiej Cybulski \\ ORCID 0000-0002-9529-1976 \\ Mateusz Kujawiński \\ ORCID 0000-0002-0313-2776 \\ Agnieszka Węgierska \\ ORCID 0000-0001-9128-259X \\ Politechnika Łódzka, Instytut Automatyki \\ bkcybulski@gmail.com, mateusz.kujawinski.92@gmail.com, wegierska.agnieszka@gmail.com
}

\title{
UDZIAŁ W MIĘDZYNARODOWYCH KONKURSACH ROBOTYCZNYCH JAKO NOWA FORMA PODRÓŻY STUDENCKICH
}

\begin{abstract}
Abstrakt: W artykule przedstawiono możliwości odbywania podróży zagranicznych przez studentów uczestniczących w międzynarodowych konkursach, w szczególności w zawodach robotycznych, popularnych między innymi wśród polskich studentów. Jak pokazują zebrane dane zawody te przyciągnęły nawet kilka tysięcy uczestników w ciągu ostatnich lat. Zaprezentowany został dodatkowy efekt ich uczestnictwa w konkursach, jakim jest turystyka uprawiana w trakcie takich wyjazdów i nazwana przez autorów turystyką konkursową.
\end{abstract}

Słowa kluczowe: turystyka konkursowa, Stany Zjednoczone, studenci, łazik marsjański.

\section{WPROWADZENIE}

Druga połowa XX w. oraz obecny wiek XXI to czas rozkwitu badań kosmicznych. Dawne, odległe plany eksploracji Układu Słonecznego stały się realne. Jednak mimo postępu technologicznego misje bezzałogowe dominują nad misjami załogowymi. Tak upragniona przez ludzi wizja turystyki kosmicznej dopiero zaczyna się powoli rozwijać (RóŻYCKI, WYSOCZYŃSKA 2011, RÓŻYCKI, KRUCZEK 2017). W odniesieniu do misji bezzałogowych prym wiodą misje z wykorzystaniem tzw. łazików, czyli robotów, mogące się poruszać po powierzchni obiektu, na którym wylądowały. Do tej pory udało się przeprowadzić misje lazików księżycowych i marsjańskich. W niniejszym artykule skupiono się jednak przede wszystkim na turystycznym aspekcie wyjazdów studentów na konkursy robotyczne, związane $\mathrm{z}$ drugą wymienioną grupą łazików. Bardzo często udział $w$ takich zawodach, poza pomijanym $w$ szczegółowych opisach zasadniczym celem wyjazdów, czyli uczestnictwem w konkursie, jest jedyną szansą na dalekie podróże studentów z różnych krajów, zwłaszcza takich, jak: Indie, Bangladesz czy Polska. Podkreślono też ekonomiczny aspekt odbywania się takich konkursów. Dzięki organizacji tego rodzaju wydarzeń, jak pokazano na podstawie studium przypadku z USA, zyskuje bowiem lokalna turystyka i często miasteczka, które stają się bazami noclegowymi dla przybywających bardzo licznie na konkursy robotyczne uczestników. Korzyści z organizacji takich zawodów mogą być obustronne: studenci poszerzają horyzonty naukowe oraz $\mathrm{w}$ zakresie krajoznawstwa, z kolei miasta, które są gospodarzami zawodów, osiągają w tym czasie dochody wysoko ponad średnią sezonową.

W niniejszym artykule zostaną zaprezentowane najpopularniejsze konkursy robotyczne na świecie i struktura pochodzenia drużyn reprezentujących poszczególne państwa wraz z ich polityką dotyczącą podróży zagranicznych swoich obywateli. Dane te posłużą analizie aktywności turystycznej studentów z różnych krajów w międzynarodowych zawodach robotów mo- 
bilnych. W dalszej części pracy opisane zostana dwa popularne konkursy - University Rover Challenge, organizowany w USA, i polski European Rover Challenge.

Baza danych została stworzona przez autorów opracowania głównie na podstawie zestawień i statystyk zamieszczanych na stronach internetowych organizatorów konkursów. Dane szczegółowe uzyskano dzięki zastosowaniu metody pogłębionych wywiadów z członkami jednej z polskich drużyn biorącej udział w wymienionych konkursach. Wykorzystanie wyników badań posłuży realizacji założenia niniejszej pracy, którym jest wyodrębnienie przez autorów nowej formy turystyki, nazwanej przez nich turystyką konkursową.

\section{PODRÓŻOWANIE STUDENTÓW}

Motyw podróży towarzyszył studentom z całego świata od wieków. W zależności od epoki ich podróże przybierały różne formy. W czasach starożytnych studenci potrafili pokonywać setki kilometrów, by móc uczyć się i zdobywać wiedzę od ówczesnych mentorów określonej dziedziny życia. Podobna sytuacja miała miejsce również $\mathrm{w}$ średniowieczu, kiedy zaczynały powstawać szkoły wyższe. Przyszli studenci opuszczali rodzinne strony i udawali się w podróż do wybranych uniwersytetów w odległych zakątkach Europy, aby móc zdobywać cenną i niedostępną dla wszystkich wiedzę. Wiek XXI to nowe trendy migracji na świecie. Migracje studenckie przybrały wiele nowych form. Obecnie to wyjazdy nie tylko dające możliwość studiowania na zagranicznych uczelniach, ale również ich zwiedzania. Od roku 2004 systematycznie rośnie udział studentów zagranicznych w wielu państwach Europy (największy wzrost dotyczy Holandii, Danii, Hiszpanii, Polski, Czech, czy też Belgii). Wśród przyjeżdżających najliczniejsze grupy stanowią studenci z Chin, Arabii Saudyjskiej, Wietnamu (OKÓLSKI 2017). Z globalnego punktu widzenia najwięcej studentów zagranicznych docelowo wybiera Stany Zjednoczone, Wielką Brytanię i Australię - dominują zatem kraje anglojęzyczne (HUT, JAROSZEWSKA 2011). Zagraniczni studenci w 2009 r. najczęściej wyjeżdżali do Europy $(46 \%)$, w następnej kolejności wybierali Amerykę Północną (23\%) oraz Azję (11\%).

H. VARASTEH, A. MARZUKI i S.M. RASOOLIMANESH (2014) analizowali czynniki, które wpływają na zachowania podróżnicze studentów. Według nich decydujące znaczenie mają takie elementy, jak: wiek, stan cywilny oraz narodowość. Najmniej istotnymi czynnikami oddziałującymi na zachowania podróżnicze są: płeć, reprezentowana uczelnia, odbyte staże czy długość trwania podróży. Ważną kwestią jest również dostęp do informacji turystycznych, zamiesz- czanych w macierzystych uczelniach. Część studentów decyzję o wybranym kierunku podróży podejmuje dopiero po rozmowach $\mathrm{z}$ rówieśnikami, którzy mieli już okazję odbyć podobne wyjazdy zagraniczne. Preferowanymi celami wyjazdów są wycieczki do parków narodowych, na festiwale lub do muzeów (MICHAEL, ARMSTRONG, KING 2003).

Wzrost migracji studentów z całego świata to jednak nie tylko podróże do zagranicznych ośrodków naukowych w ramach wymiany studentów, czy też realizacji programów stażowych $\mathrm{w}$ międzynarodowych korporacjach. Wraz z rozwojem nowych technologii coraz częściej pojawiają się okazje do zagranicznych wyjazdów, których liczba z roku na rok sukcesywnie rośnie, np. konkursy związane z robotyką. Uczestnicy takich zawodów zgodnie twierdzą, że to doskonała możliwość testowania tworzonych przez nich rozwiązań naukowych oraz czynnik napędzający rozwój nowych technologii. Udział $\mathrm{w}$ tego typu konkursach to również kolejna okazja dla określonej grupy studentów do odbycia zagranicznego wyjazdu turystycznego. Skłania to do próby wyszczególnienia jeszcze jednej gałęzi studenckich podróży po świecie, a mianowicie podróży krajoznawczych w ramach konkursów robotycznych dla studentów.

\section{METODY I BAZA DANYCH}

Na potrzeby niniejszego opracowania została zbudowana obszerna baza danych, zawierająca opisy 278 drużyn z kilkunastu krajów uczestniczących w zawodach robotycznych. Dane dotyczą ostatnich 11 lat w przypadku konkursu University Rover Challenge oraz trzech lat dla European Rover Challenge. W tym celu skorzystano $z$ list konkursowych, umieszczanych na stronach internetowych organizatorów zawodów (http:// roverchallenge.eu/pl/home/, http:// urc.mars society.org/). Ponadto źródłem potrzebnych informacji były witryny internetowe, prowadzone przez poszczególne drużyny z całego świata, oraz fanpage'e drużyn w mediach społecznościowych. W celu uzupełnienia ewentualnych luk $\mathrm{w}$ danych był utrzymywany kontakt mailowy z drużynami i organizatorami konkursów. Baza danych przygotowana została $\mathrm{w}$ formie tabelarycznej, zawierającej następujące elementy: liczba zgłoszeń i finalistów w poszczególnych latach, opisy drużyn i ich struktury, wyniki konkursów, polityka wizowa. Ze względu na ograniczony dostęp do danych osobowych (ich ochrona) liczbę osób w drużynie szacowano poprzez wizję lokalną oraz analizy informacji zawartych w wymienianych wcześniej źródłach.

Analizy aspektów turystycznych, wpisujących się w podróże studenckie $\mathrm{w}$ ramach konkursów robotycznych, dokonano na podstawie informacji pozy- 
skanych za pośrednictwem metody pogłębionych wywiadów IDI (MIŃSKI 2017). Wywiady zostały przeprowadzone z członkami łódzkiej drużyny Raptors (10 wywiadów). Dzięki tej metodzie otrzymano dokładne i szczegółowe informacje na temat finansowania tego typu podróży, preferencji bazy noclegowej, środków transportu, a także innych elementów turystycznych, z jakich korzystali członkowie zespołu Raptors. Pozostałe informacje, odnoszące się do lokalnych atrakcji turystycznych, zostały uzupełnione na podstawie zagranicznych witryn internetowych oraz przewodników turystycznych. Z kolei dane na temat bazy noclegowej pozyskano za pomocą portalu booking.com.

\section{CHARAKTERYSTYKA ZAWODÓW ROBOTYCZNYCH}

Dynamiczny rozwój robotyki na świecie wywołał konkurencję i potrzebę organizowania konkursów robotycznych przeznaczonych zarówno dla uczniów szkól, studentów, ośrodków badawczych, jak i profesjonalnych firm. Rywalizacja powoduje, że w kolejnych edycjach konkursu wystawiane są przez różne kraje coraz bardziej zaawansowane technologicznie konstrukcje. Atrakcyjność tej dziedziny skutkuje podnoszeniem wysokości nagród pieniężnych, które z kolei pozwalają zwycięzcom na zakup lepszego sprzętu i tym samym napędzają rozwój. W artykule omówione zostaną niektóre, przeznaczone dla studentów konkursy robotyczne (przedstawione $\mathrm{w}$ tab. 1), podczas których drużyny mogą dokonać weryfikacji działania konstrukcji w rzeczywistych warunkach. Konkurencje, z jakimi zmagają się zespoły, dotyczą realnych problemów, w których robotyka znajduje zastosowanie, jak np. eksploracja odległych planet czy działania inspekcyjno-ratunkowe. Konkursy studenckie umożliwiają też nawiązanie kontaktów i wymianę informacji pomiędzy studentami z różnych uczelni na świecie.

Dwa najważniejsze konkursy w branży robotycznej (URC iERC) organizowane sa przez The Mars Society (rys. 1). The Mars Society jest największą na świecie organizacją mającą na celu zasiedlanie planety Mars oraz jego eksplorację. Założona przez dr. Roberta Zubrina i innych w 1998 r. grupa pracuje nad edukacją społeczeństwa, mediów i rządów na temat korzyści płynących z eksploracji Marsa i nad przyszłym osiedleniem się człowieka na Czerwonej Planecie. Na potrzeby naukowe stworzone zostały dwie symulowane stacje badawcze, imitujące marsjańskie środowisko. Pierwsza z nich - Flashline Mars Arctic Research Station (FMARS) - znajduje się na wyspie Devon w kanadyjskiej Arktyce. Druga z kolei - Mars Desert Research Station (MDRS) - połżona jest w pobliżu Hanksville, w amerykańskim stanie Utah (https://en. wikipedia. org/wiki/Mars_Society).

Tab. 1. Zestawienie omawianych światowych studenckich konkursów robotycznych

\begin{tabular}{|c|c|c|c|c|}
\hline Lp. & Nazwa konkursu & Logotyp & Kraj & Charakterystyka zawodów \\
\hline 1 & $\begin{array}{l}\text { University Rover } \\
\text { Challenge } \\
\text { (URC) }\end{array}$ & & USA & $\begin{array}{c}\text { Zawody łazików marsjańskich przeznaczone są dla drużyn } \\
\text { studenckich, składających się w większości ze studentów } \\
\text { pierwszego i drugiego stopnia } \\
\text { (https:/ / en.wikipedia.org/wiki/Mars_Society) }\end{array}$ \\
\hline 2 & $\begin{array}{l}\text { European Rover } \\
\text { Challenge } \\
\text { (ERC) }\end{array}$ & & Polska & $\begin{array}{l}\text { Podobnie jak URC od } 2018 \text { r. wprowadzono zmagania } \\
\text { profesjonalistów, w których mogą brać udział m.in. firmy, } \\
\text { ośrodki badawcze (http:/ / roverchallenge.eu/pl/o-erc/) }\end{array}$ \\
\hline 3 & $\begin{array}{c}\text { Canadian } \\
\text { International Rover } \\
\text { Challenge (CIRC) } \\
\end{array}$ & & Kanada & \multirow{2}{*}{$\begin{array}{c}\text { Kolejne konkursy przeznaczone dla studentów ukierunkowane } \\
\text { na rozwój technologii i rozwiązań kosmicznych } \\
\text { (https:/ / circ.cstag.ca/about, } \\
\text { https:/ / www.mbzirc.com/) }\end{array}$} \\
\hline 4 & $\begin{array}{l}\text { Indian Rover } \\
\text { Challenge (IRC) }\end{array}$ & & Indie & \\
\hline 5 & $\begin{array}{c}\text { Mohamed Bin } \\
\text { Zayed International } \\
\text { Robotics Challenge } \\
\text { (MBZIRC) }\end{array}$ & 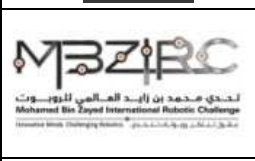 & $\begin{array}{l}\text { Zjednoczone } \\
\text { Emiraty } \\
\text { Arabskie }\end{array}$ & $\begin{array}{c}\text { Zawody przeznaczone dla robotów lądowych i latających, } \\
\text { ukierunkowane na rozwój autonomii i zaawansowanych } \\
\text { technologii } \\
\text { (https:/ / www.mbzirc.com/) }\end{array}$ \\
\hline 6 & $\begin{array}{l}\text { World Robot } \\
\text { Summit } \\
\text { (WRS) }\end{array}$ & & Japonia & $\begin{array}{l}\text { Zawody robotów inspekcyjnych, ratunkowych, usługowych, } \\
\text { połączone z wystawą technologiczną } \\
\text { (http:// worldrobotsummit.org/en/) }\end{array}$ \\
\hline 7 & $\begin{array}{l}\text { ERL Emergency } \\
\text { Service Robots }\end{array}$ & $\begin{array}{l}\text { EUROPEAN } \\
\text { ROBOTICS } \\
\text { LEAGUE } \\
\text { Brought to you by SPARC }\end{array}$ & $\begin{array}{l}\text { Włochy, } \\
\text { Hiszpania }\end{array}$ & $\begin{array}{c}\text { Zawody heterogenicznych robotów mobilnych, prowadzących } \\
\text { działania inspekcyjno-ratunkowe, przeznaczone dla drużyn } \\
\text { studenckich, ośrodków badawczych i firm } \\
\text { (https:// www.eurobotics.net/robotics_league/about/the- } \\
\text { european-robotics-league/index.html) }\end{array}$ \\
\hline
\end{tabular}




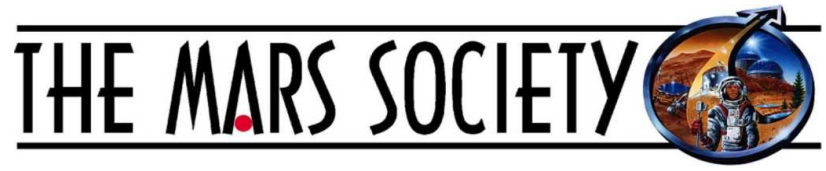

Rys. 1. Logotyp organizacji Mars Society

Źródło: http:/ / urc.marssociety.org/

To właśnie MDRS zmienia się corocznie, nieustannie od 2007 r., na przełomie maja i czerwca w pole manewrowe dla łazików marsjańskich, konstruowanych przez studentów z całego świata. Przez trzy dni trwają tam największe, najbardziej znane i prestiżowe zawody, czyli University Rover Challenge (URC). Drużyny konstruktorów rywalizują w konkurencjach związanych z eksploracją i badaniem terenu, transportem przedmiotów na obszarze do $1 \mathrm{~km}$, precyzyjnymi zadaniami manipulacyjnymi oraz autonomiczną jazdą "po punktach". Operatorzy lazika w trakcie trwania konkurencji przebywają w stacji bazowej, a do sterowania robotem wykorzystują tylko dane $\mathrm{z}$ czujników i kamer, czyli znajdują się w takiej samej sytuacji, jak operatorzy łazików w trakcie misji marsjańskich (http:/ / urc.marssociety.org/).

Młodszym konkursem, także o randze międzynarodowej, rozgrywającym się na kontynencie europejskim, jest European Rover Challenge (ERC), odbywający się na terenie Polski. Do tej pory zawody przeprowadzono w 2014, 2015, 2016 i 2018 r. ERC pozwala zweryfikować postępy $\mathrm{w}$ rozwoju i wdrażaniu nowych technologii przez studentów z całego świata. Zadania, z jakimi zmagają się drużyny, zbliżone są do konkurencji na URC i dotyczą m.in. prezentacji zespołu i poboru próbek gleby do późniejszej analizy fizyko-chemicznej. O randze konkursu świadczy fakt pojawienia się międzynarodowych gości związanych $\mathrm{z}$ astronautyką, automatyką i robotyką oraz założyciela organizacji The Mars Society dr. Roberta Zubrina (http:// roverchallenge.eu/pl/o-erc/).

Mars Society organizuje także konkursy Canadian International Rover Challenge (CIRC) oraz Indian Rover Challenge (IRC), których konkurencje wzorowane są na URC. Zawody CIRC rozgrywane są od $2017 \mathrm{r}$. w lipcu w Drumheller w Kanadzie (https:/ / circ.cstag. ca/about/). Indian Rover Challenge odbywa się na początku stycznia na terenie uczelni technicznej w Manipalu. W konkursie występują ograniczenia wagowe i budżetowe, które pozwalają podjać rywalizację niżej finansowanym zespołom (https://www.indianrover challenge.in/).

Kolejnym centrum rozwoju badań z zakresu robotyki są Zjednoczone Emiraty Arabskie, gdzie co dwa lata odbywają się zawody Mohamed Bin Zayed International Robotics Challenge (MBZJRC). Jest to młody konkurs, gdyż pierwsza edycja została przeprowadzona w 2017 r. Zasady wyboru drużyn są bardzo restrykcyjne, ostatecznie $\mathrm{w}$ roku 2017 zakwalifikowa- nych zostało 25 zespołów, które rywalizowały w kilku konkurencjach przeznaczonych dla robotów lądowych i latających. Zadania zorientowane były na rozwój autonomicznych systemów sterowania pojazdów bezzałogowych, które potrafią rozpoznawać i śledzić obiekty, poruszać się po terenie $\mathrm{i}$ „podejmować decyzje" (https://www.mbzirc. com/).

Znaczącą pozycję $\mathrm{w}$ rozwoju robotyki ma także Japonia. W październiku 2018 r. w Tokio odbyły się zawody World Robot Challenge (WRS), połączone z wystawą technologiczną, nazwane World Robot Summit 2018. Dla zespołów studenckich wydarzenie jest doskonałą okazją do zapoznania się z najnowszymi technologiami dostępnymi na rynku, a także daje możliwość szerszego spojrzenia na wymagania stawiane robotom. W zawodach ponadto brały udział doświadczone ośrodki badawcze oraz firmy, podnosząc tym samym poziom konkursu. Jedna z rozgrywanych konkurencji dotyczyła działań inspekcyjno-ratowniczych na terenie symulowanego środowiska fabryki. Konkurencja ma na celu przygotowanie zarówno organizatorów, jak i zawodników do właściwej edycji konkursu, który odbędzie się w 2020 r. i będzie poświęcony działaniom inspekcyjno-ratunkowym na terenie rzeczywistego miejsca katastrofy w elektrowni atomowej w Fukushimie (http:/ / worldrobotsummit.org/en/).

Na uwagę zasługuje również konkurs Emergency Service Robots (ESR), organizowany od 2016 r. przez European Robots League (ERL) - Europejską Ligę Ro-botyki, w którym biorą udział nie tylko zespoły studenckie, ale również ośrodki badawcze i przemysłowe. Podczas zawodów drużyny zmagają się z zadaniami odwzorowującymi rzeczywistą sytuację kryzysową, związaną np. z atakiem tsunami. Organizatorzy zwracają uwagę na istotę współpracy heterogenicznych robotów mobilnych podczas wspólnej akcji inspekcyjno-ratunkowej prowadzonej pod wodą, na lądzie i w powietrzu. Wyzwania konstruktorskie, stojące przed zespołami, powodują, że często dochodzi do współpracy pomiędzy drużynami, które muszą ustalić w jaki sposób będą się wymieniać informacjami, ze względu na brak możliwości z braku możliwości bezpośredniej komunikacji między operatorami podczas wspólnej misji (https://www.eu-robotics.net /robotics_league/about/the-european-robotics-league /index. html).

\section{OMÓWIENIE WYNIKÓW}

W analizowanych konkursach robotycznych ERC i URC biorą udział studenci z 16 państw: Bangladeszu, Egiptu, Hiszpanii, Holandii, Indii, Kanady, Kolumbii, Korei Południowej, Meksyku, Nepalu, Polski, Turcji, Stanów Zjednoczonych, Wielkiej Brytanii, Włoch oraz 
Australii (rys. 2). W bazie danych zestawiono konkursy URC od 2007 r. i ERC od 2014. Najwięcej reprezentantów w konkursach robotycznych mają Stany Zjednoczone oraz Polska. Na kolejnych pozycjach plasuja się Indie i Kanada, a także Bangladesz. Pozostałe państwa wysłały pojedyncze reprezentacje (rys. 2).

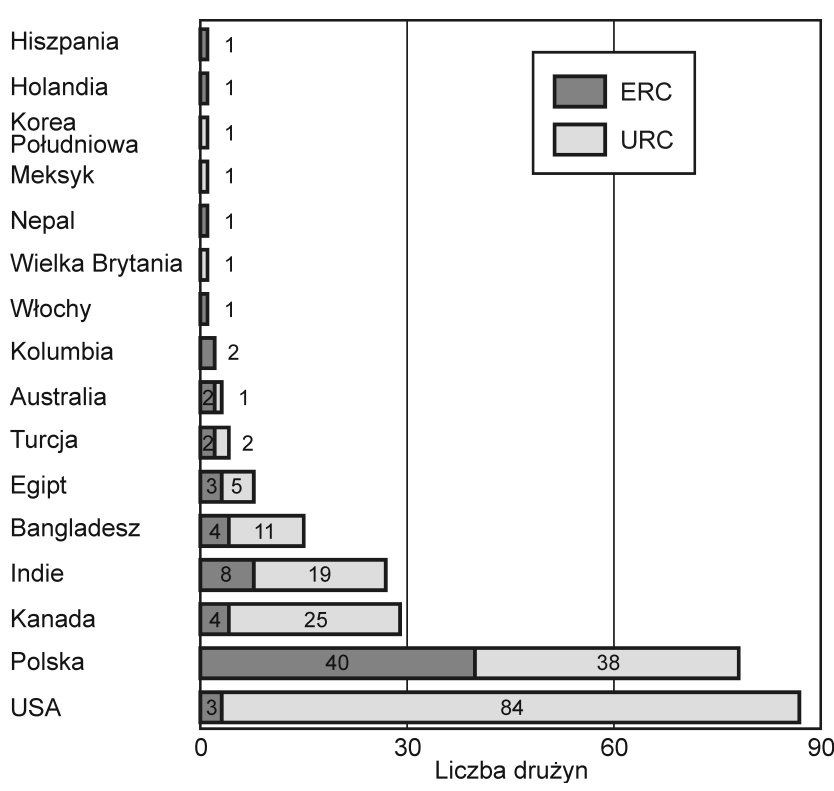

Rys. 2. Liczba drużyn konkursów robotycznych z poszczególnych państw we wszystkich edycjach zawodów URC i ERC Źródło: http:/ / urc.marssociety.org//, http:/ / roverchallenge.eu/pl/home//

Na turystyczne podróże studenckie, odbywane w ramach wyjazdów na konkursy (nie tylko z sektora robotyki), duży wpływ mają między innymi uwarunkowania polityczne, które nieustannie się zmieniają. W odniesieniu do dwóch konkursów analizowanych $\mathrm{w}$ niniejszym artykule istotne znaczenie ma polityka wizowa Stanów Zjednoczonych. $W$ tab. 2 zostały zaprezentowane państwa wraz z sytuacją wizową.

Tab. 2. Wymagania wizowe wobec obywateli państw, których drużyny biorą udział w konkursach robotycznych URC i ERC

\begin{tabular}{|l|l|}
\hline $\begin{array}{c}\text { System bezwizowy } \\
\text { (Visa Waiver Program) }\end{array}$ & \multicolumn{1}{|c|}{ Wymagana wiza USA } \\
\hline Hiszpania & Egipt \\
\hline Holandia & Indie \\
\hline Korea Południowa & Kolumbia \\
\hline Wielka Brytania & Meksyk \\
\hline Włochy & Nepal \\
\hline Kanada (odrębne ustalenia) & $\begin{array}{l}\text { Polska (kraj nominowany } \\
\text { do programu bezwizowego) }\end{array}$ \\
\hline- & $\begin{array}{l}\text { Turcja (kraj nominowany } \\
\text { do programu bezwizowego) }\end{array}$ \\
\hline
\end{tabular}

Źródło: https://pl.usembassy.gov//.
Można zauważyć, że aż trzy (Polska, Indie, Bangladesz) z pięciu najliczniej reprezentowanych państw należą do grupy, w której istnieje obowiązek posiadania wizy do Stanów Zjednoczonych. Jest to dodatkowe obciążenie finansowe dla studentów oraz konieczność spełnienia wymagań administracyjnych. Niespełnienie wymagań wizowych skutkuje nieotrzymaniem pozwolenia na wjazd do USA, a tym samym blokadę udziału w konkursie URC. W przypadku zawodów ERC o wiele prościej mają drużyny z Europy, w których obowiązują zasady migracyjne Unii Europejskiej. Reprezentanci pozostałych krajów są zobowiązani do wystąpienia o wizy, które pozwolą im przebywać na obszarze Rzeczypospolitej, i tym samym na terenie UE.

Analizując zmiany liczebności uczestników obserwuje się wraz z upływem czasu stały wzrost liczby drużyn zarówno w konkursach URC, jak i ERC (rys. 3 i 4). Ogromny wpływ na taką sytuację ma fakt coraz większej otwartości na zagraniczne pomysły, międzynarodową wymianę myśli i idei. Oba analizowane konkursy składają się z eliminacji oraz konkursu finałowego, w którym występuje określona liczba drużyn. W finale znajdują się drużyny, które przeszły preeliminacje i zostały zaproszone do występu podczas zawodów.

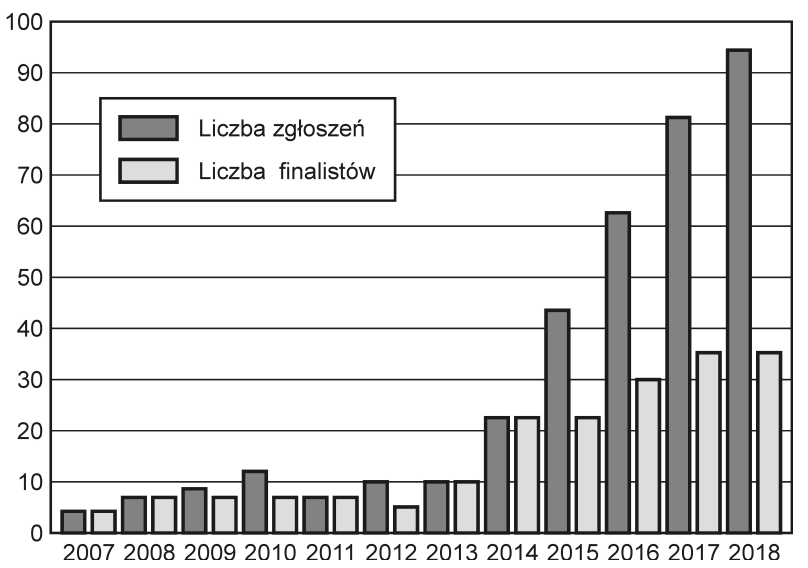

Rys. 3. Liczba zgłoszeń drużyn studenckich i finalistów w konkursie robotycznym URC w poszczególnych latach Źródło: http:/ / urc.marssociety.org/

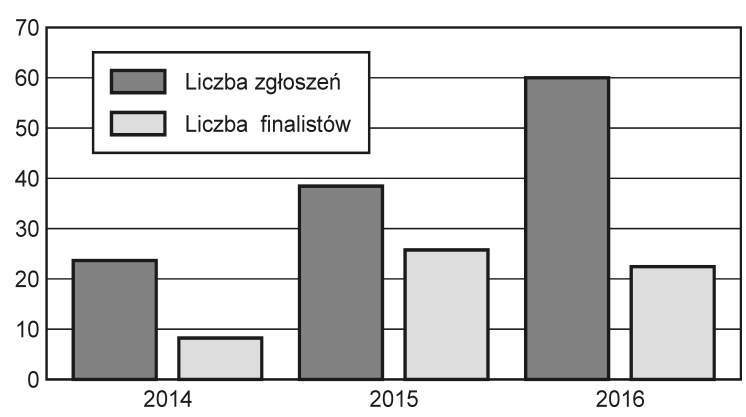

Rys. 4. Liczba zgłoszeń drużyn studenckich i finalistów w konkursie robotycznym ERC według lat (2014-2016) Źródło: http:/ / roverchallenge.eu/pl/home/ 
Tab. 3. Szacowana liczba uczestników z poszczególnych państw biorących udział w konkursach robotycznych URC i ERC

\begin{tabular}{|c|c|c|c|c|c|c|c|c|}
\hline \multirow{4}{*}{ Państwo } & \multirow{2}{*}{\multicolumn{2}{|c|}{$\begin{array}{l}\text { Udział wszystkich } \\
\text { drużyn we wszystkich } \\
\text { edycjach konkursów }\end{array}$}} & \multicolumn{6}{|c|}{ Suma osób w drużynie, przy założeniu } \\
\hline & & & \multicolumn{2}{|c|}{$\begin{array}{l}\text { minimalnej ich liczby } \\
\text { (6 osób) }\end{array}$} & \multicolumn{2}{|c|}{$\begin{array}{l}\text { maksymalnej ich liczby } \\
\text { (20 osób) }\end{array}$} & \multicolumn{2}{|c|}{$\begin{array}{c}\text { średniej ich liczby } \\
\text { (12 osób) }\end{array}$} \\
\hline & \multicolumn{8}{|c|}{ Zawody } \\
\hline & ERC & URC & ERC & URC & ERC & URC & ERC & URC \\
\hline Australia & 2 & 1 & 12 & 6 & 40 & 20 & 24 & 12 \\
\hline Bangladesz & 4 & 13 & 24 & 78 & 80 & 260 & 48 & 156 \\
\hline Egipt & 3 & 5 & 18 & 30 & 60 & 100 & 36 & 60 \\
\hline Hiszpania & 1 & 0 & 6 & 0 & 20 & 0 & 12 & 0 \\
\hline Holandia & 1 & 0 & 6 & 0 & 20 & 0 & 12 & 0 \\
\hline Indie & 8 & 19 & 48 & 114 & 160 & 380 & 96 & 228 \\
\hline Kanada & 4 & 25 & 24 & 150 & 80 & 500 & 48 & 300 \\
\hline Kolumbia & 2 & 0 & 12 & 0 & 40 & 0 & 24 & 0 \\
\hline Korea Południowa & 0 & 1 & 0 & 6 & 0 & 20 & 0 & 12 \\
\hline Meksyk & 0 & 1 & 0 & 6 & 0 & 20 & 0 & 12 \\
\hline Nepal & 1 & 0 & 6 & 0 & 20 & 0 & 12 & 0 \\
\hline Polska & 40 & 38 & 240 & 228 & 800 & 760 & 480 & 456 \\
\hline Turcja & 2 & 2 & 12 & 12 & 40 & 40 & 24 & 24 \\
\hline USA & 3 & 84 & 18 & 504 & 60 & 1680 & 36 & 1008 \\
\hline Wielka Brytania & 0 & 1 & 0 & 6 & 0 & 20 & 0 & 12 \\
\hline Włochy & 1 & 0 & 6 & 0 & 20 & 0 & 12 & 0 \\
\hline
\end{tabular}

Źródło: http:/ / urc.marssociety.org//, http:/ / roverchallenge.eu//, badania własne.

Drużyny zarówno w konkursie URC, jak i ERC liczyły od 6 do 20 osób. Średnio każdy zespół składał się z 12 członków (tab. 3). W każdej z drużyn jest więcej mężczyzn niż kobiet. Najczęściej przewaga jest trzykrotna, zdarzają się pojedyncze przypadki, w których drużyna składa się wyłącznie z mężczyzn. Najprawdopodobniej spowodowane jest to faktem, że uczelnie, z których przyjeżdżają studenci, są szkołami technicznymi. Na takich uczelniach wśród studentów przeważają mężczyźni. Przykładem mogą być wyższe szkoły techniczne $\mathrm{w}$ Polsce, $\mathrm{w}$ których udział kobiet wynosi 36,8\% (Szkoty wyższe... 2015). Osoby, które uczestniczą w konkursach, studiują najczęściej na kierunkach: automatyka i robotyka, elektrotechnika, mechatronika, mechanika i budowa maszyn oraz informatyka. Odsetek kobiet na wymienionych kierunkach jest bardzo niski i wynosi odpowiednio: automatyka i robotyka-9,1\%, elektrotechnika - $6 \%$, mechatronika $-8,3 \%$, mechanika i budowa maszyn $-8,6 \%$ oraz informatyka - 11,7\% (Raport... 2017).

W ramach uczestnictwa w zawodach ERC we wszystkich edycjach przyjechało do Polski od 192 do 640 studentów z całego świata (nie licząc studentów z Polski), czyli średnio w edycji uczestniczyły 384 osoby. Razem ze studentami z Polski, dla których wyjazd na taki konkurs również jest szansą na podróże turystyczne, liczba ta wynosi odpowiednio od 432 do 1440 osób, tj. przeciętnie 854 osoby. Najwięcej studentów przyleciało z Indii (od 48 do 160), najmniej z Nepalu, Holandii i Włoch (6-20 osób) (tab. 3).

Analizując liczbę studentów, wziąwszy pod uwagę kontynent ich pochodzenia, można stwierdzić, że najwięcej osób przyleciało z Azji (Indie, Bangladesz, Nepal), tj. od 78 do 260 osób. Pod tym względem Europa (bez studentów z Polski) plasuje się dopiero na trzecim miejscu, za Ameryką Północną (tab. 3, rys. 5).

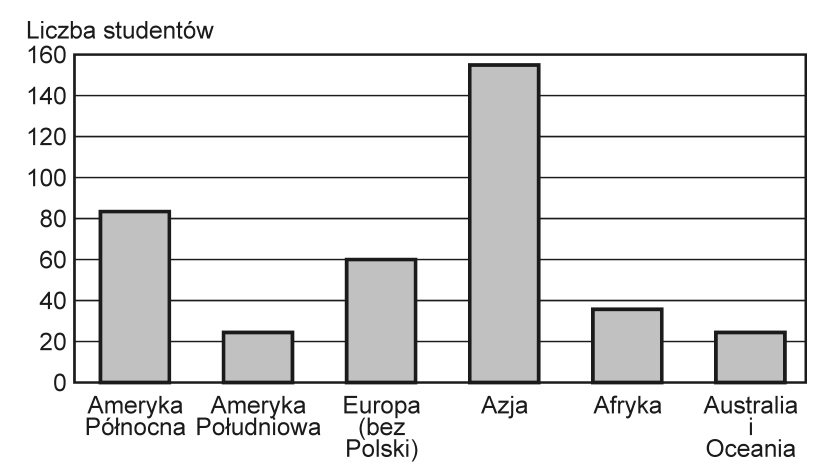

Rys. 5. Średnia liczba studentów reprezentujących poszczególne kontynenty w zawodach ERC od początku trwania konkursu Źródło: http:// roverchallenge.eu

Liczba studentów z różnych części świata, którzy przylecieli na zawody do USA (bez studentów z USA), wynosi od 636 do 2120 (średnio 1272 osoby). Jeśli doliczy się studentów z USA, liczba ta powiększa się od- 
powiednio, według edycji, od 1140 do 3800 osób (średnio - 2280). Najwięcej osób przyleciało z Europy, czyli od 246 do 820 studentów, z czego 92,68\% stanowią studenci z Polski (rys. 6). Dalej plasują się kolejno reprezentanci Azji i Ameryki Północnej (głównie studenci z Kanady). Od początku organizowania konkursu URC nie przybyła żadna drużyna z Ameryki Południowej. Spowodowane jest to najprawdopodobniej skomplikowanym systemem przyznawania wiz mieszkańcom tego rejonu świata.

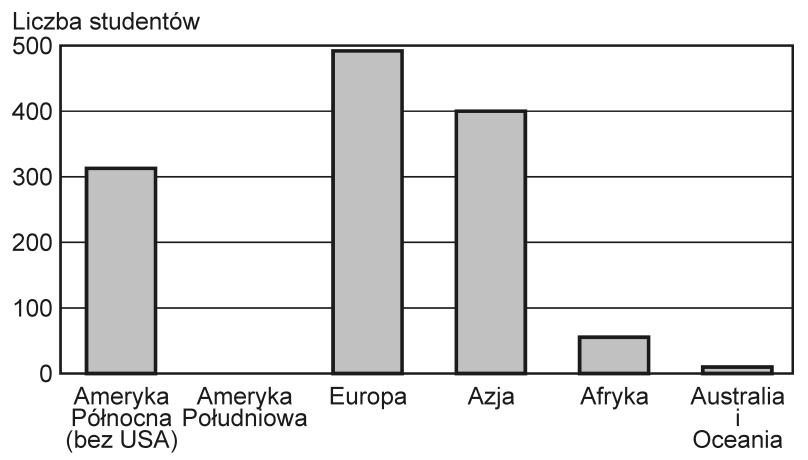

Rys. 6. Średnia liczba studentów z poszczególnych kontynentów uczestniczących w zawodach URC od początku trwania konkursu

Źródło: http:/ / urc.marssociety.org /, badania własne

\section{ASPEKT TURYSTYCZNY UCZESTNICTWA W ŚWIATOWYCH KONKURSACH ROBOTYCZNYCH}

Aspekt turystyczny omawianych w niniejszym opracowaniu wyjazdów studentów nie jest oczywiście celem konkursów robotycznych. Zwiedzanie i korzystanie z atrakcji turystycznych jest dla uczestników zawodów URC elementem dodatkowym, wynikającym z okazji do eksploracji niezwykle ciekawego i atrakcyjnego obszaru USA. Odbywanie podróży turystycznych przez różne drużyny w czasie odbywania się zawodów URC można potraktować tożsamo. $Z$ tego względu autorzy niniejszego artykułu przeprowadzili studium przypadku polskiej drużyny Raptors, oparte na ponadpięcioletnich doświadczeniach jej członków. Poniżej zostaną omówione szczegółowo warunki samego wyjazdu oraz możliwości czerpania z niego korzyści turystycznych.

Drużynę Raptors, która rozwija technologie w zakresie robotyki mobilnej, stanowi grupa studentów i doktorantów z Politechniki Łódzkiej i jest wspierana przez doktorantów Uniwersytetu Łódzkiego. Zespół tworzy 12 osób pracujących w zakresie automatyki, robotyki, elektroniki, mechaniki, informatyki, badań środowiskowych oraz organizacji. Dla członków drużyny aspekt turystyczny w czasie trwania konkursu robotycznego URC jest częścią relaksu i chwilą wytchnienia po intensywnym wysiłku umysłowym.

Wyjazd na zawody jest tak naprawdę tylko zwieńczeniem długiego okresu pracy i przygotowań, a dostanie się do finału konkursu - gratyfikacją za poczynione przez drużynę postępy $\mathrm{w}$ rozwoju konstruowanego robota. Na możliwość uczestniczenia w zawodach składają się takie elementy, jak: środki finansowe, dojazd do miejsca odbywania się konkursu, pobyt tam i powrót do kraju.

Zdobycie finansów dla drużyny polskiej jest jednym z kluczowych zadań pozwalających na podjęcie podróży zagranicznej. Wysokość uzyskanych środków wpływa zarówno na długość pobytu, jak i liczbę uczestników mogących wziąć udział w wyjeździe, a fakt ten bezpośrednio przekłada się na potencjał turystyczny podróży. W tym miejscu trzeba zwrócić szczególną uwagę na cel, który definiuje potrzebę finansową - stanowią ją zawody w USA. Wyjazd tam to bardzo długa i droga podróż dla drużyny z Polski. Inaczej jest $w$ przypadku drużyn amerykańskich, przyjeżdżających na europejską edycję zawodów - skala ich wydatków jest nieporównanie mniejsza.

Do wyznaczenia minimalnego okresu trwania pobytu na zawodach jest brany pod uwagę czas trwania konkursu, czas podróży oraz czas niezbędny na przygotowanie robota do konkursu. Drużynom przyjeżdżającym z odległych krajów ten ostatni czynnik pochłania więcej czasu. Często wiąże się to bowiem z dodatkowymi pracami, takimi jak: odbiór skrzyni ze sprzętem, montaż/demontaż robota oraz ponowne jej nadanie po zakończeniu zawodów.

Określenie optymalnej długości czasu trwania podróży jest indywidualne dla każdego zespołu i zależy od przyjętych kryteriów związanych z kosztami, czasem trwania konkursu, a także $z$ walorami turystycznymi znajdującymi się $w$ niedużej odległości od wybranej drogi dojazdu do miejsca organizacji zawodów. Każdy dodatkowy dzień wykraczający poza minimum pozwala na swobodniejsze planowanie podróży, pobytu, pracy nad zadaniami konkursowymi oraz lepszą organizację turystycznego aspektu wyjazdu.

Na podstawie doświadczenia polskiej drużyny Raptors można przyjąć, że minimalnym czasem wyjazdu na zawody jest 11-12 dni. Wykres kosztów wyjazdu, w funkcji jego długości nie jest funkcją liniową. Czasami niewielkie zwiększenie budżetu znacznie wpływa na długość pobytu całej drużyny w miejscu odbywania się konkursu URC. W praktyce koszty wyjazdu można podzielić na: koszty stałe, takie jak: wysyłki robota, wizy, przelotów, czyli niezmieniające się w zależności od długości wyjazdu, i koszy zmienne, tj. noclegi, wyżywienie, wynajem aut. Na podstawie doświadczeń drużyny Raptors można wyliczyć, że koszty stałe na jednego członka grupy 10-osobowej wynoszą około $6000 \mathrm{zl}$, a koszty zmienne blisko 
350 zł dziennie. Można z tego wywnioskować, że krótkie wyjazdy są ekonomicznie nieopłacalne, a nawet niewielkie wydłużenie wyjazdu może diametralnie wzbo-gacić aspekty poznawcze młodych ludzi, przy niewielkim wzroście kosztów podróży. Dla przykładu, koszt 12-dniowego wyjazdu dla grupy 10 osób wyniesie około $100000 \mathrm{zl}$, natomiast wyjazd dłuższy o sześć dni (tj. o 50\%) zwiększy tę sumę zaledwie o $22000 \mathrm{zl}$, co stanowi wzrost wydatków o jedyne $22 \%$. W trakcie tych dodatkowych sześciu dni drużyna jest w stanie odwiedzić większość atrakcji turystycznych stanów Utah, Nevady oraz Kalifornii, m.in. Wielki Kanion, Kanion Antylopy, Dolinę Śmieci (fot. 1), oraz zwiedzić takie miasta, jak Los Angeles i Las Vegas.

Zawody w USA odbywają się w centralnej części stanu Utah. Z punktu widzenia drużyny zagranicznej dojazd na zawody jest utrudniony z powodu dużej odległości miejsca odbywania zawodów od najbliższego lotniska międzynarodowego. Takie lotniska znajdują się w Los Angeles, Salt Lake City, San Francisco, Las Vegas oraz Denver. W przypadku drużyny Raptors dotychczas zawsze wybierany był port lotniczy w Los Angeles, oddalony o 1027 km od bazy zawodów. Wybór nie był przypadkowy i wynikał z większej dostępności lotów z Polski, odpowiedniej bazy noclegowej, dużej liczby wypożyczalni samochodów oraz wysokiego potencjału turystycznego. W przypadku podróży międzykontynentalnej drużyny zawsze doliczają kilka dni po przylocie na załatwienie formalności, np. wynajmu auta, które jest podstawowym środkiem transportu w USA, odbioru robota itp. Okres ten pozwala na aklimatyzację w nowym środowisku i wstępne zapoznanie się $\mathrm{z}$ terenem oraz kulturą danego miejsca. Droga do miejsca odbywania się zawo-
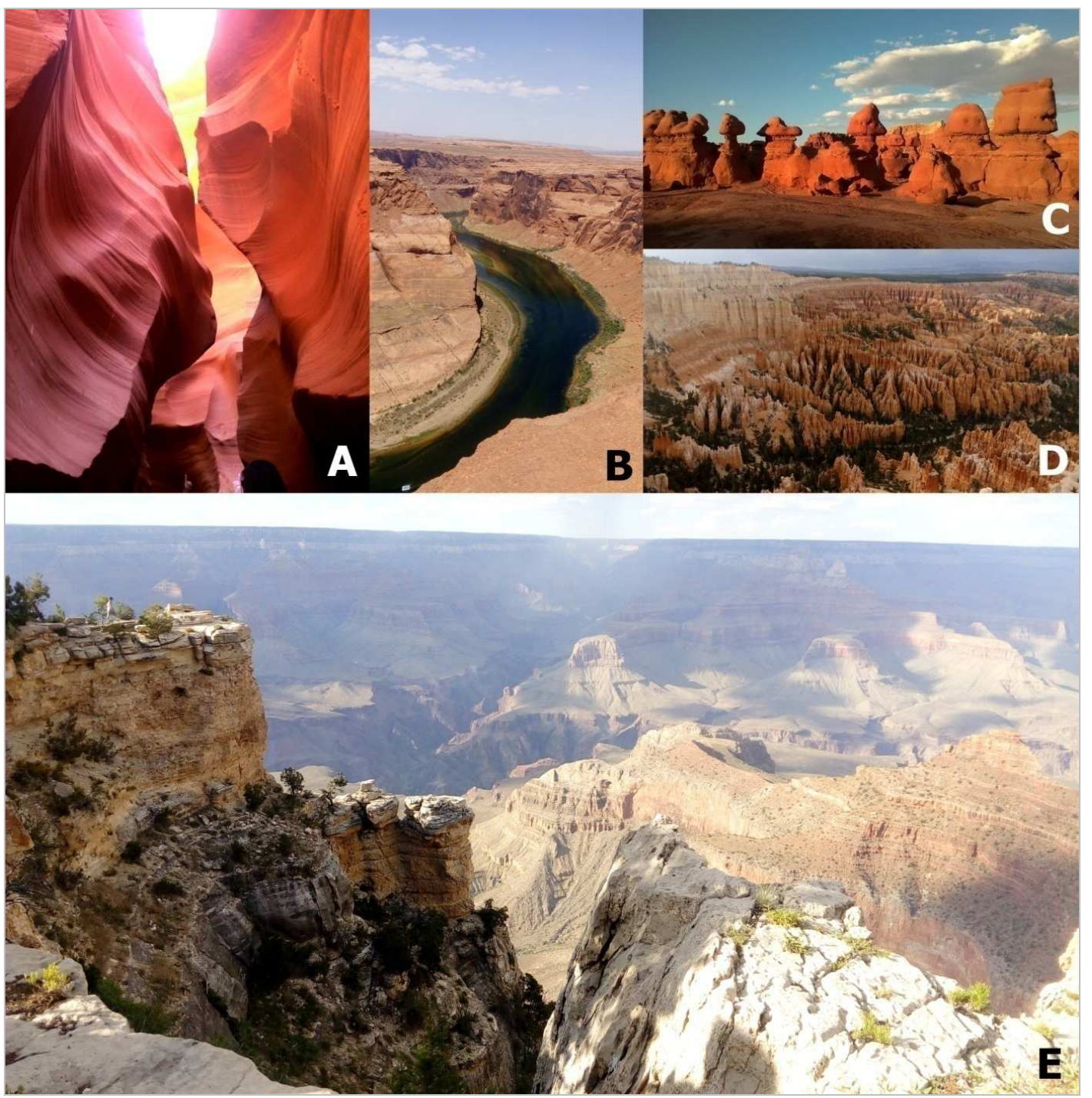

Fot. 1. Charakterystyczne punkty turystyczne, związane z podróżą na zawody robotyczne URC A - Kanion Antylopy, B - Kanion Glen, tzw. HorseshoeBend,

C - Dolina Goblinów, D - Kanion Bryce, E - Wielki Kanion Colorado Źródło: fot. A i C - Wiktor Piech (2017), fot. B, D i E - Luiza Wieczorek (2017) 
dów jest pokonywana z wykorzystaniem dróg lądowych, przez co aspekty turystyczne same wpisują się w taką podróż. Jednymi z największych atrakcji turystycznych $\mathrm{w}$ trakcie podróży są: tama Hoovera, droga 66, Joshua Tree National Park, Las Vegas, Bryce Canyon czy Zion National Park.

Przeciętnie podróż na obszar odbywania się zawodów zajmuje dwa-trzy dni, a miejscem przystanku pośredniego jest Las Vegas. Drużyny najczęściej zatrzymują się tam na jedną-dwie noce. Miasto jest znane przede wszystkim z kasyn oraz hoteli. Populacja miasta w roku 2017 wynosiła 641676 mieszkańców (www.fact finder.census.gov), a liczba pokoi hotelowych w tym czasie - aż 148690 (www.statista.com). Licencjonowanych miejsc gier hazardowych jest ponad 1700, natomiast automatów do gry niecałe 200000 (www. tripsavvy.com). Najwięcej kasyn i hoteli znajduje się przy bulwarze Las Vegas Strip. Najczęściej spotyka się tam połączenie hotelu i kasyna w jednym budynku. Najciekawszymi wizualnie tego typu obiektami są: Luxor - mający kształt czarnej, szklanej piramidy, a także Excalibur - zbudowany na wzór średniowiecznego zamku lub Caesars Casino, gdzie wnętrze stylizowane jest na starożytny Rzym i średniowieczną Wenecję. Równie interesującymi z punktu widzenia architektury dużymi hotelami-kasynami są też: Mandalay Bay, Treasure Island, Monte Carlo, Bellagio czy The Mirage. Przed kasynem The Mirage można podziwiać „erupcję” kilkunastometrowego wulkanu, która ma miejsce każdego wieczoru. Wspaniałym widowiskiem może się poszczycić również Bellagio, przed którym każdej nocy odbywa się spektakl polegający na synchronizacji wody, muzyki i światła (Fountains of Bellagio). Kasyno New York - New York Hotel \& Casino jest również bardzo ciekawym budynkiem, stylizowanym architektonicznie na Nowy Jork. Stoi przed nim 46-metrowa replika Statui Wolności, a wokół obiektu rozciąga się kolejka górska. Ponadto można tam zobaczyć wieżę Eiffla w skali 1 : 2, mającą około 165 m wysokości, oraz Łuk Triumfalny wielkości $2 / 3$ obiektu oryginalnego.

Obrany plan dojazdu do miejsca zawodów wskazuje, iż odwiedziny wymienionych atrakcji są krótkie i mają charakter powierzchowny, mimo to pozwalają uczestnikom wyprawy zobaczyć kluczowe i najbardziej popularne miejsca turystyczne tego rejonu USA.

Przygotowania do wyjazdu do Stanów Zjednoczonych rozpoczyna się już około sześciu miesięcy przed terminem samych zawodów. Baza noclegowa na obszarze odbywania się konkursu nie jest dobrze rozbudowana, a bliskie położenie takich obiektów, jak m.in. Capitol Reef National Park lub Arches National Park, które odwiedza ponad 2,5 mln osób rocznie, (https:/ / irma.nps.gov) jest jednym z powodów, dla których znalezienie noclegu dla większej grupy na okres kilku dni nie jest zadaniem łatwym. Mimo że zawody odbywają się w pobliżu Hanksville, najbliższe większe bazy noclegowe - Torrey i Green River - znajdują się ponad $80 \mathrm{~km}$ od miejsca zawodów, gdzie jest tylko kilka moteli, kilka restauracji oraz mały sklep wielobranżowy. Duże dystanse, jakie i tak musi pokonać drużyna do miejsca organizacji zawodów, stwarzają możliwość wyboru bazy noclegowej najbardziej optymalnej z punktu widzenia dojazdu na konkurs, ale również jako bazy wypadowej do zwiedzania lokalnych atrakcji turystycznych. Kolejnymi wyznacznikami branymi pod uwagę są: cena noclegu, bliskość do głównego szlaku komunikacyjnego oraz dostępność łącza internetowego.

Okres bezpośrednio przed zawodami służy do złożenia robota, który przybył do USA drogą lotniczą, oraz przygotowania go do konkurencji konkursowych. Prace najczęściej odbywają się już w bazie noclegowej. Na aktywność turystyczną w tym czasie składają się krótkie wyprawy krajoznawcze do blisko zlokalizowanych atrakcji turystycznych. Najczęściej są to miejsca oddalone kilkanaście kilometrów od bazy noclegowej, a same wycieczki nie trwają dłużej niż dwie-trzy godziny. Zazwyczaj są to parki narodowe znajdujące się $\mathrm{w}$ bezpośrednim sąsiedztwie bazy noclegowej, jak np. Capitol Reef NP. Dodatkową formą aktywności turystycznej jest wyjazd na okoliczne „bezdroża" w celu przeprowadzenia testu terenowego robota. Takie wyprawy pozwalają na lepsze poznanie okolicy i odwidzenie miejsc, których nie wymienia się w przewodnikach turystycznych, a są bardzo ciekawe.

Przez trzy dni konkursu jego uczestnicy mają do wykonania cztery zadania-misje. Również w tym czasie mogą wygospodarować kilka efektywnych godzin na aktywność turystyczno-krajoznawczą, bowiem przebywają na terenie interesującej pustyni. Zwiedzanie ogranicza się do najbliższej okolicy terenu zawodów, czyli sąsiedztwa Mars Desert Research Station, oraz obejmuje przydrożne atrakcje turystyczne na trasie przejazdu do motelu. Na tym obszarze najstarszymi antropogenicznymi atrakcjami krajoznawczymi, znajdującymi się przy drodze prowadzącej na teren zawodów, są: Mummy Cliff, Capitol Reef oraz rysunki naskalne wczesnych ludów indiańskich, które przedstawiają formy ludzkie i zwierzęce (rys. 7).

Mogłoby się wydawać, że pustynia będąca obszarem zawodów robotycznych jest nieatrakcyjna, ale jej krajobraz robi ogromne wrażenie na odbiorcy. Zwłaszcza kontrast ostańców z piaskowców lub mułowców z płaskimi terenami (fot. 2). Dodatkowo, około $3 \mathrm{~km}$ w głąb pustyni od miejsca zawodów znajduje się tzw. Dino Park (wykopalisko dinozaurów), będący jedną z atrakcji, którą można odwiedzić między zadaniami konkursowymi. W pobliżu miejsca odbywania się zawodów znajduje się również park stanowy Goblin Valley, dokąd można wybrać się również w przerwie w zajęciach związanych z konkursem. 
Najlepszy czas na odbycie podczas wyjazdu na konkurs URC podróży turystycznej pojawia się po zakończeniu zawodów. Możliwości zwiedzania przez drużyny spoza USA w dużej mierze zależą od długości pobytu, czyli pośrednio od zdobytych środków finansowych. W odległości jednego dnia drogi od miejsca zawodów zlokalizowanych jest dziewięć ważnych atrakcji turystycznych, a szczególnie interesująca wydaje się południowa część stanu Utah i północny fragment

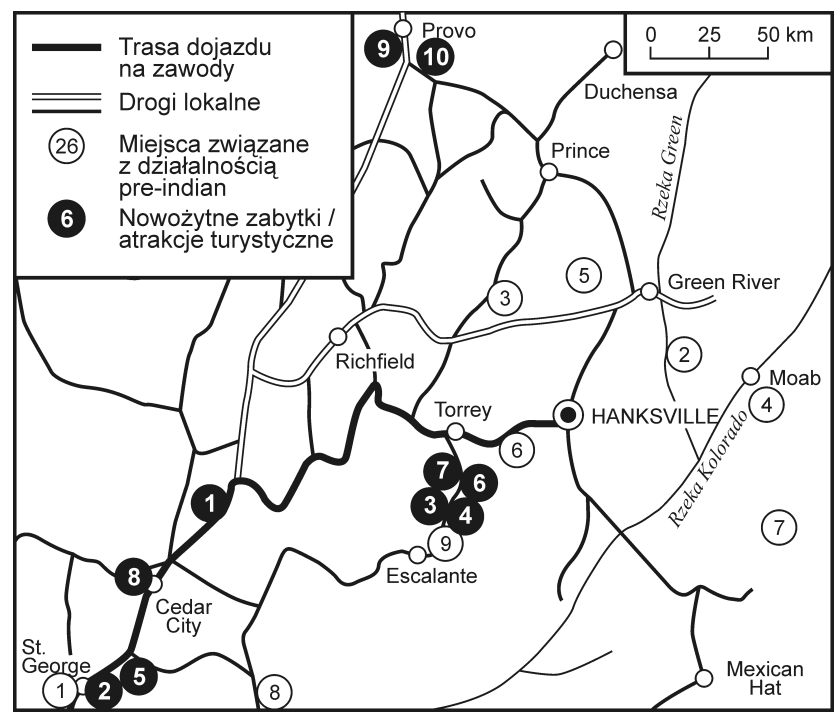

Rys. 7. Zabytki i atrakcje w pobliżu miejsca organizacji zawodów robotycznych URC - Hanksville (Utah, USA)

Miejsca związane z działalnością pre-Indian: 1 - Bloomington Petroglyph Park, 2 - Rochester Rock, 3 - Barrier Canyon (Horseshoe Canynon), 4 - obszar Moab, 5 - San Rafael Swell 6 - Capitol Reef, 7 - Mule Canyon Ruins, 8 - Moqui Cave, 9 - Anasazi Indian Village State Park; nowożytne zabytki/atrakcje: 1 - Cove Fort, 2 - Brigham Young Winter Home Historical Site, 3 - Gifford Homestead w Capitol Reef, 4 - Fruita, 5 - Jacob Hamblin House, 6 - Behunin Cabin, 7 - Pioneer Register, 8 - Old Iron Town, 9 - Provo City Center Temple, 10 - Brigham Young University

Źródło: B. PRETTYMAN (2017), http://utah.com/, http://www.visitutah.com/
Arizony. Tam znajdują się m.in.: Wielki Kanion, Kanion Antylopy, Bryce National Park, Zion NP, Horseshoe Bend, Monument Valley, których zwiedzenie wymaga trzech-czterech dodatkowych dni (rys. 8).

Bardzo często polska drużyna Raptors mijała ekipy z innych krajów, które również zwiedzały zachodnią część Stanów Zjednoczonych. Można zatem mówić o pojawiającym się trendzie $\mathrm{w}$ zachowaniach turystycznych studentów biorących udział w zawodach

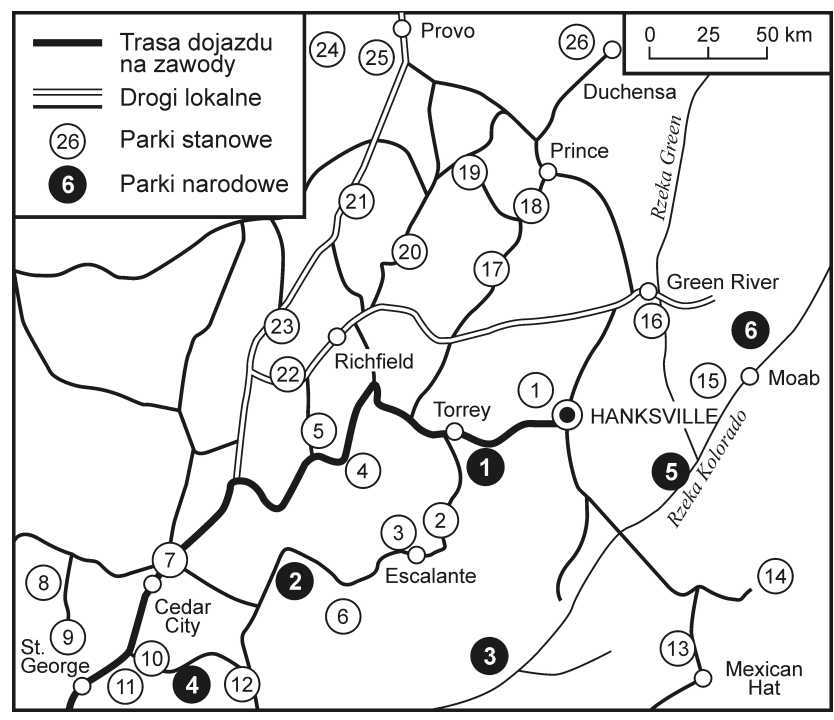

Rys. 8. Parki stanowe i narodowe USA w pobliżu trasy dojazdu do Hanksville w stanie Utah - miejsca odbywania się zawodów robotycznych URC

Parki stanowe: 1 - Dolina Goblinów, 2 - Muzeum Anasazi, 3 - Las Escalante Petrified, 4 - Otter Creek, 5 - Piute, 6 - Kodachrome Basin, 7 - Frontier Homestead, 8 - Gunlock, 9 - Kanion Snow, 10 - Quail Creek, 11 - Sand Hollow, 12 - Coral Pink Sand Dunes, 13 - Goosenecks, 14 - Edge of the Cedars, 15 - Dead Horse Point, 16 - Green River, 17 - Millsite, 18 - Huntington, 19 - Scofield, 20 - Palisade, 21 - Yuba, 22 - Fremont Indian, 23 - Terrtorial Starehouse, 24 - Camp Floyd, 25 - Utah Lake, 26 - Starvation; parki narodowe: 1 - Capitol Reef, 2 - Kanion Bryce,

3 - Kanion Glen, 4 - Zion, 5 - Canyonlands, 6 - Arches Źródło: B. PRETTYMAN (2017), http://utah.com/, http://www.visitutah.com/

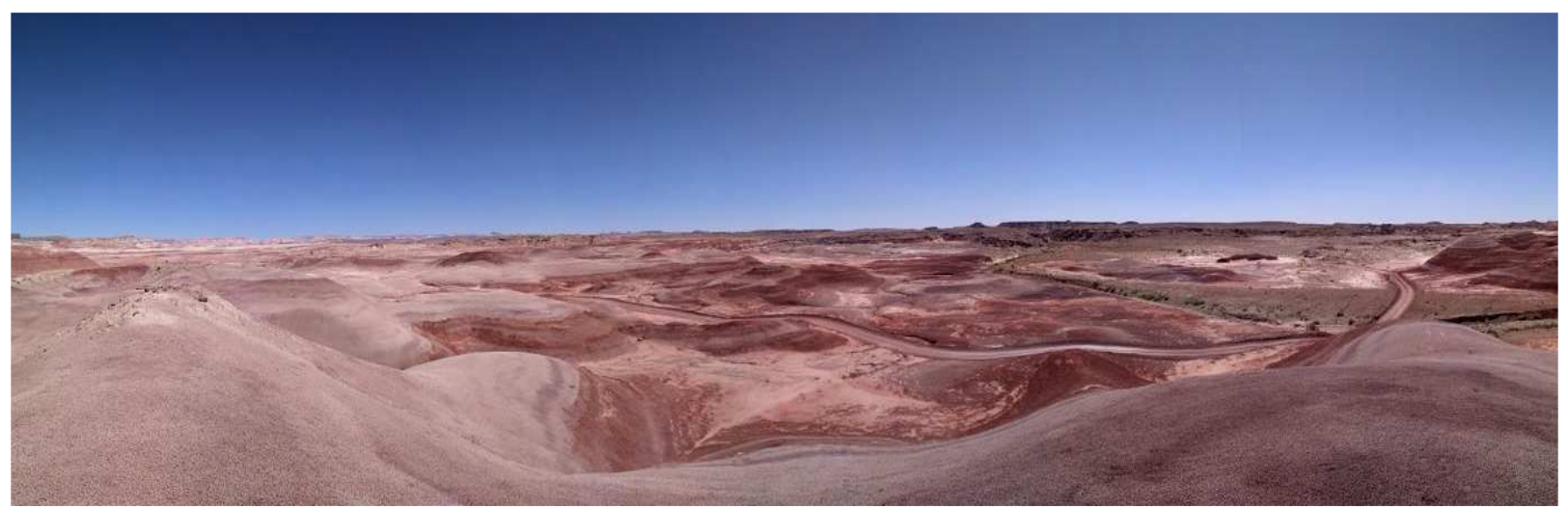

Fot. 2. Pustynia w stanie Utah (USA) w sąsiedztwie miasta Hanksville - obszar odbywania się zawodów robotycznych URC Źródło: fot. B. Cybulski (2017) 
robotycznych w USA, a mianowicie wykorzystania obecności na zawodach, aby zwiedzić tę część USA. Autorzy proponują określenie takiego zjawiska mianem turystyki konkursowej. Termin ten odnosiłby się do turystycznych migracji osób w celu uczestniczenia w konkursach/zawodach, podczas których w czasie dojazdu, pobytu i powrotu z bazy konkursowej (noclegowej) wykonywane są czynności i zachowania turystyczne. W pierwszej kolejności wybierane są miejsca turystyczne występujące bardzo blisko głównego szlaku komunikacyjnego, który prowadzi od bazy noclegowej do miejsca zawodów. W przypadku USA taki dystans wynosi $20-50 \mathrm{~km}$ od głównego szlaku komunikacyjnego, a dla Polski 5-10 km. Kolejnymi sposobnościami krajoznawczymi są - jak już wspomniano - wyjazdy turystyczne, zazwyczaj krótkie, w bliskim zasięgu bazy konkursowej/noclegowej. Odległość taka w przypadku USA oscyluje w granicach 50-100 km, a dla Polski 10-50 km. Tak rozumianą turystykę konkursową można by podzielić na dwa typy: krajową i międzynarodową. Typ pierwszy odnosi się do osób, których narodowość jest tożsama z krajem, w którym odbywa się konkurs, a typ drugi dotyczy tych uczestników, którzynie pochodzą z tego kraju.

\section{PODSUMOWANIE}

Autorzy niniejszego artykułu skupili się na analizie nowego trendu w odbywaniu podróży turystycznych przez niektórych studentów. Podróże, o których mowa, dotyczyły wyjazdów młodych ludzi na międzynarodowe konkursy robotyczne i wykorzystanie faktu znalezienia się na interesującym krajoznawczo obszarze do zwiedzenia, ,przy okazji”, znajdujących się tam atrakcji turystycznych. W celu kompleksowego podejścia do problemu, nieporuszanego dotąd w artykułach naukowych, autorzy sporządzili specjalną bazę danych. Posłużyły do tego statystyki prowadzone przez organizatorów konkursów oraz informacje uzyskane z witryn internetowych drużyn konkursowych studentów z całego świata. Szczegółowe dane pozyskano za pośrednictwem metody pogłębionego wywiadu z członkami polskiej drużyny z Łodzi - zarejestrowanej pod nazwą Raptors.

Międzynarodowe konkursy robotyczne, rozgrywane na całym świecie, pozwalają na walidację rozwijanej technologii oraz przyczyniają się do rozwoju turystyki w pobliżu miejsca odbywania się zawodów. Dla studentów udział w takich konkursach stanowi gratyfikację za trud włożony w skonstruowanie robotów. Współzawodnictwo zachęca do dalszej pracy nad nimi, dzięki czemu studenci poszerzają swoją wiedzę, a także rozwijają umiejętności interpersonalne.
W opracowaniu poddane zostały analizie dwa najważniejsze konkursy z dziedziny robotyki - University Rover Challenge i European Rover Challenge. W zawodach URC na przestrzeni wszystkich lat udział brało 106 drużyn z 10 krajów (bez USA), natomiast w konkursach ERC - 30 drużyn z 12 krajów (bez Polski). W turystyce konkursowej dużą rolę odgrywa polityka migracyjna państwa, w którym odbywa się dany konkurs. Pomimo konieczności posiadania wizy do USA przez studentów, m.in. z Polski, Indii, Bangladeszu, oraz dużej odległości pomiędzy tymi krajami a miejscem zawodów URC, pod względem liczby startujących drużyn Polska zajmuje drugie miejsce (po USA), Indie i Bangladesz odpowiednio czwarte i piąte miejsce. W przypadku zawodów ERC, mimo łagodnych przepisów migracyjnych w Unii Europejskiej, wzięły w nich udział pojedyncze drużyny z państw zrzeszonych w UE.

Nieodłącznym elementem odbywanych przez studentów podróży w ramach udziału w konkursach z różnych dziedzin jest aspekt turystyczny. Studenci nie zawsze mają okazję odbywać prywatnie podróże zagraniczne, zwłaszcza międzykontynentalne. Wyjazd na konkurs stwarza zatem niepowtarzalną możliwość poznania atrakcji turystycznych danego miejsca, mimo że nie jest ono głównym celem tego typu podróży. Jednym z kluczowych elementów takiej wyprawy jest zdobycie odpowiednich środków finansowych. Kiedy już są środki na wyjazd drużyny w odległe miejsca organizowanych konkursów, to nieznaczne wydłużenie pobytu $\mathrm{w}$ niewielkim tylko stopniu podwyższa koszty takiej podróży.

Konkurs URC w niniejszym artykule stał się tłem analizy aspektów turystycznych wyjazdów na zawody robotyczne drużyn z całego świata. Zawody URC odbywają się pośrodku pustyni w Symulowanej Bazie Marsjańskiej NASA - MDRS w stanie Utah w USA. Taka lokalizacja wpływa na konieczność częstego przemieszczania się z bazy noclegowej do bazy zawodów, co owocuje możliwością odkrywania walorów turystycznych okolic miejsca odbywania się konkursów. Autorzy artykułu zaobserwowany przez siebie nowy trend w podróżach studenckich nazwali turystyką konkursową. Wyróżniono jej dwa typy - turystykę konkursową krajową oraz turystykę konkursową międzynarodową.

\section{BIBLIOGRAFIA}

Hut P., JAROSZEWSKA E., 2011, Studenci zagraniczni w Polsce na tle migracji edukacyjnych na świecie, Instytut Spraw Publicznych, Warszawa.

MiCHAEL I., ARMSTRONG A., KING B., 2003, The travel behavior of international students: The relationship between studying abroad and their choice of tourist destinations, "Journal of Vacation Marketing", 10 (1), s. 57-66. 
MiŃSKI R., 2017, Wywiad pogłębiony jako technika badawcza. Możliwości wykorzystania IDI w badaniach ewaluacyjnych, „Przegląd Socjologii Jakościowej", XIII, 3, s. 30-51.

OKÓLSKI M., 2017, Nowa, krucha mapa europejskich migracji, „Studia Migracyjne - Przegląd Polonijny", 1 (163), s. 5-28.

PRETTYMAN B., 2017, The Utah travel guide. Life elevated, Utah Office of Tourism, Film and Global Branding.

Raport. Kobiety na politechnikach 2007-2017, 2017, Fundacja Edukacyjna "Perspektywy”, marzec.

RÓŻYCKI P., KRUCZEK Z., 2017, Turystyka kosmiczna: historia i przysztość oraz jej miejsce w typologii turystyki kulturowej, [w:] S. Owsianowska, R. Winiarski (red.), Antropologia turystyki, ser. Monografia, 35, s. 173-189.

RÓŻYCKI P., WYSOCZYŃSKA B., 2011, Space tourism - a twenty-first century phenomenon, „New Problems of Tourism”, 1 (4).

Szkoty wyższe $i$ ich finanse w 2015 roku, 2016, GUS, Warszawa.

VARASTEH H., MARZUKI A., RASOOLIMANESH S.M., 2014, Factors affecting international student's Ravel behaviour, "Journal of Vacation Marketing", 21 (2), s. 1-19. http://roverchallenge.eu/pl/home/; 29.11.2018.

http://roverchallenge.eu/pl/o-erc/; 29.11.2018.

http:/ / urc.marssociety.org/; 29.11.2018.

http://utah.com/; 30.11.2018.

http://worldrobotsummit.org/en/; 29.11.2018.

http://www.visitutah.com/;30.11.2018.

https:/ /en.wikipedia.org/wiki/Mars_Society; 29.11.2018.

https://irma.nps.gov; 30.11.2018.

https://pl.usembassy.gov; 25.11.2018.

https:/ / www.eu-robotics.net/robotics_league/about/the-euro

pean-robotics-league/index.html; 29.11.2018.

https://www.indianroverchallenge.in/; 29.11.2018.

https://www.mbzirc.com/; 29.11.2018.

www.factfinder.census.gov; 25.11.2018.

www.tripsavvy.com; 25.11.2018.

www.statista.com; 25.11.2018.

www.booking.com; 25.11.2018.

Artykuł wpłyną:

21 września 2018 r.

Zaakceptowano do druku:

4 listopada $2018 \mathrm{r}$. 